\title{
An Annotated Checklist of Elasmobranchs Along the Coromandel Coast of Tamil Nadu, Southeast Coast of India
}

\author{
M. Kishore Kumar, N. Jayakumar, K. Karuppasamy, D. Manikandavelu, A. Uma
}

10.18805/IJAR.B-4281

\begin{abstract}
Background: Elasmobranch is one of the largest marine fish resources, consisting of sharks, sawfishes, rays and skates. A worldwide estimate of elasmobranch diversity reveals 815 species coming under 9 orders, 42 families and 164 genera, of which 359 species are sharks and 456 are skates and rays. Hence, it has been planned to investigate the biodiversity and fishery of elasmobranchs along the Coromandel Coast of Tamil Nadu, Southeast India.

Methods: Elasmobranch specimens were collected during June 2019 to March 2020 from three main landing centres of Coromandel Coast of Tamil Nadu viz Royapuram (Chennai), Cuddalore and Nagapattinam Fishing Harbours. Sampling was done fortnightly in the above three landing centres. The specimens were collected from the catches of trawl nets, bottom set gillnets and hook and lines. The specimens were identified morphologically in the landing centres itself based on the valid taxonomic keys.

Result: In the present study, 67 species of elasmobranch belonging to 7 orders, 21 families and 46 genera were recorded. Of the 7 orders, Carcharhiniformes had the largest number of species (27). Among the 25 families, Carcharhinidae (21) had the largest representation.
\end{abstract}

Key words: Checklist, Coromandel coast, Elasmobranch diversity.

\section{INTRODUCTION}

Chondrichthyans include all cartilaginous fish species commonly called sharks, rays, skates and chimaeras. They are widely distributed in all the world's oceans, but are most diverse in the tropical and subtropical Indo-Pacific Ocean (Bonfil, 2002). A worldwide estimate of elasmobranch diversity revealed 815 species coming under 9 orders, 42 families and 164 genera, of which 359 species are sharks and 456 are skates and rays. Among them, 28 species are primarily from freshwaters (Nelson, 1994). The earliest compilations of chondrichthyan diversity in Indian waters reported 69 species (Day, 1889), 52 species (Misra, 1952), 114 species (Misra, 1969). Compagno (1984) listed 55 species of sharks from Indian Ocean. Raje et al. (2002) listed 110 species and Venkataraman et al., (2003) prepared a field identification handbook on sharks containing 72 species. Raje et al. (2007) prepared an atlas on the elasmobranch resources consisting of 84 species from Indian seas. Recent compilation of Akhilesh et al. (2014) reported 227 species of Chondrichthyans from Indian seas and the diversity is higher than reported in many other tropical Ocean countries. Gowthaman (2011) reported 73 species of elasmobranchs belonging to 6 orders, 21 families and 42 genera from the Gulf of Mannar. Ganesh and Geetha (2017) investigated elasmobranch by-catch diversity and reported 24 species of elasmobranch belonging to 6 orders, 10 families and 11 genera in the same region. Joshi et al. (2016) reported 51 species of sharks belonging to 25 genera, 15 families and 7 orders from the Gulf of Mannar. Thilaka et al. (2017) reported 45 species of sharks from the same region. Karuppasamy et al. (2020) reported 44 species of elasmobranchs belonging to 8 orders, 13 families and 25 genera occurring along the Wadge Bank, South India.
Dr. M.G.R Fisheries College and Research Institute, Tamil Nadu Dr. J. Jayalalithaa Fisheries University, Ponneri-601 204, Tamil Nadu, India.

Corresponding Author: N. Jayakumar, Dr. M.G.R Fisheries College and Research Institute, Tamil Nadu Dr. J. Jayalalithaa Fisheries University, Ponneri-601 204, Tamil Nadu, India.

Email: jayakumar@tnfu.ac.in

How to cite this article: Kumar, M.K., Jayakumar, N. and Karuppasamy, K., Manikandavelu, D. and Uma, A. (2021). An Annotated Checklist of Elasmobranchs Along the Coromandel Coast of Tamil Nadu, Southeast Coast of India. Indian Journal of Animal Research. DOI: 10.18805/IJAR.B-4281.

Submitted: 14-08-2020 Accepted: 09-06-2021 Online: 03-08-2021

The annual landing of elasmobranch resources was estimated to be 43,736 tonnes in India during 2019. Sharks and rays contributed $36.98 \%$ and $53.23 \%$ respectively whereas skates and guitar fishes contributed $9.78 \%$ to the total elasmobranch landings in the country (CMFRI, 2020). Tamil Nadu and Gujarat were the major contributors. The west coast accounted for $50.5 \%$ of the landings and east coast accounted for $49.5 \%$. All India landings of elasmobranchs during 2013-17 was 48,735 tonnes constituting $6 \%$ of demersal catch. Trawl nets accounted for $48.8 \%$, gillnets $35.6 \%$ and hook and line units $6 \%$ of the total elasmobranch landings of the country (CMFRI, 2019). However, elasmobranch research is very much limited along the Coromandel coast of Tamil Nadu, Southeast coast of India despite its rich diversity, long history and huge fishery. This paper presents an extended, updated checklist of elasmobranchs reported from Coromandel Coast of Tamil 
Nadu situated along Southeast coast of India, together with comments on the size range, length at first maturity, trophic level, dominance, status of IUCN, resilience and habitat.

\section{MATERIALS AND METHODS}

The occurrence and abundance data of different elasmobranch species were collected fortnightly from June 2019 to March 2020 from the commercial catches of trawl net, drift gill net, bottom set gill net and hook and lines from three major fish landing centres viz., Royapuram Fishing Harbour (Chennai) (Lat.1307’24.49"N; Long. 80¹7' 52.20"E), Cuddalore Fishing Harbour (Lat. 11 ${ }^{\circ} 0^{\prime} 43^{\prime \prime} \mathrm{N}$, Long. 790'45"E) and Nagapattinam Fishing Harbour (Lat. 1059'09"N, Long. 7951'09"E) situated along the Coromandel Coast of Tamil Nadu, Southeast coast of India (Fig 3). The geographical position of each sampling station was recorded with Global Positioning System (GPS). In addition to the occurrence and abundance data of various species of elasmobranch landed, the details about fishing pattern like craft specifications (types of trawlers), gear specifications (head rope length, type of otter board and cod end mesh size), fishing operations (depth of operation, trawling hour, towing and hauling speed) were also collected. In Chennai and Cuddalore Fishing Harbours, trawl nets were mainly used for elasmobranch fishing whereas longlines and gill nets were predominantly used for shark fishing and ray fishing respectively in Nagapattinam Fishing Harbour.

Some of the elasmobranch species landed were very large in size in both length and weight. The elasmobranch specimens including such large specimens were identified in the landing centre itself. But, those specimens that were difficult to identify in the field were collected and kept in an insulated ice box with ice to maintain the quality of elasmobranch till they reached the laboratory. The elasmobranch specimens were cleaned, photographed and finally preserved in $10 \%$ formalin. The specimens were identified using the guides developed by Compagno (1984), Fischer and Bianchi (1984) and Raje et al. (2007). The identity of the elasmobranch species was established without any ambiguity as these guides had pictorial keys. The elasmobranch checklist presented in this paper is based on a review of available publications, monographs and catalogues on their diversity, taxonomy, life history, ecology and fishery. For identification of species, standard taxonomical books and manuals were used (Misra, 1969; Fisher and Bianchi 1984; Compagno 1984; Venkataraman et al., 2003; Raje et al., 2007; and Kizhakudan et al., 2018). WoRMS (World Register of Marine Species); www.fishbase. org and Froese and Pauly, (2015) were also referred to confirm the name of the species and to know their status of the International Union for Conservation of Nature and Natural Resources (IUCN).

\section{RESULTS AND DISCUSSION}

In the present study, 67 species of elasmobranchs belonging to 7 orders, 21 families and 46 genera were recorded (Table 1).
Of the 7 orders of elasmobranch reported, Carcharhiniformes contributed $40 \%$ with 27 species followed by Myliobatiformes (33\%; 22 species) and by Rhinopristiformes and Torpediniformes each contributing $7 \%$ followed by Orectolobiformes, Lamniformes and Squaliformes each contributing $6 \%, 5 \%$ and $2 \%$ respectively (Fig 1). Among the 21 families, Carcharhinidae had the largest representation with 21 species followed by Dasyatidae with 12 species. This is in conformity to the study of Gowthaman (2011) who carried out a similar kind of study on elasmobranchs in the Gulf of Mannar. He reported 73 species of elasmobranchs belonging to 6 orders, 21 families and 42 genera from the Gulf of Mannar region and indicated the dominance of Carcharhiniformes with 28 species followed by Orectolobiformes ( 6 species) which are almost similar to the present study carried out along the Coromandel Coast. This is also in analogous to the study by Theivasigamani and Subbiah (2014) who reported 65 species of elasmobranchs along Thoothukudi Coast and revealed the dominance of Myliobatiformes (49.23\%) and Carcharhiniformes (32.31\%). Similarly, Ganesh and Geetha (2017) reported 24 species of elasmobranchs from the Gulf of Mannar (Tuticorin Coast) which is lower than the present study and indicated the dominance of the genus, Carcharhinus with 10 species. Further, Thilaka (2018) recorded 45 species of sharks from the Gulf of Mannar and revealed the dominance of the order, Carcharhiniformes with 32 species which is higher than the present study. Recent study by Karuppasamy et al. (2020) recorded 44 species of elasmobranch belonging to 7 orders, 13 families and 23 genera from the Wadge Bank that extends from Kanyakumari to Vizhinjam, South India and divulged the dominance of Myliobatiformes contributing 36.4\% with 17 species followed by Carcharhiniformes (34.1\%; 15 species).

Karuppasamy et al. (2020) reported that out of 44 species of elasmobranch recorded along the Wadge Bank, South India, four species were found to be under endangered and 12 species under vulnerable categories. Similarly, in the present study, out of 67 species, 22 species (33\%) were observed to be under the category 'Vulnerable',

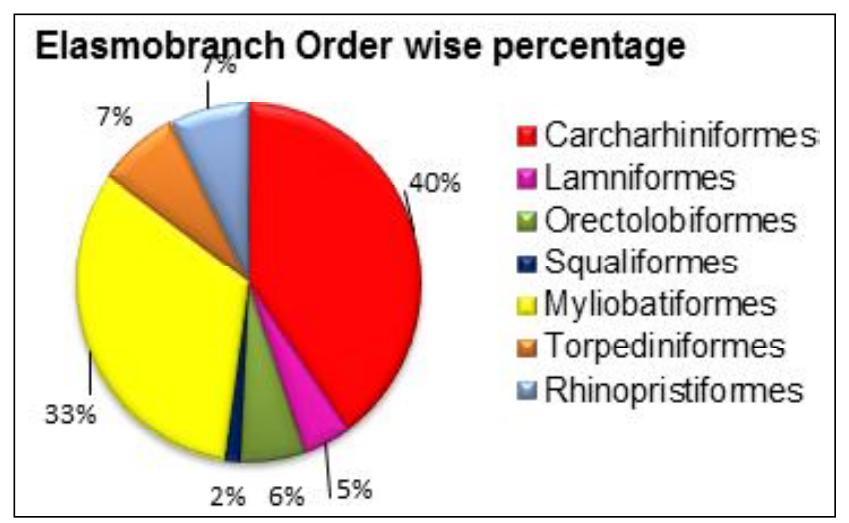

Fig 1: Order-wise elasmobranch composition. 
.An Annotated Checklist of Elasmobranchs Along the Coromandel Coast of Tamil Nadu, Southeast Coast of India

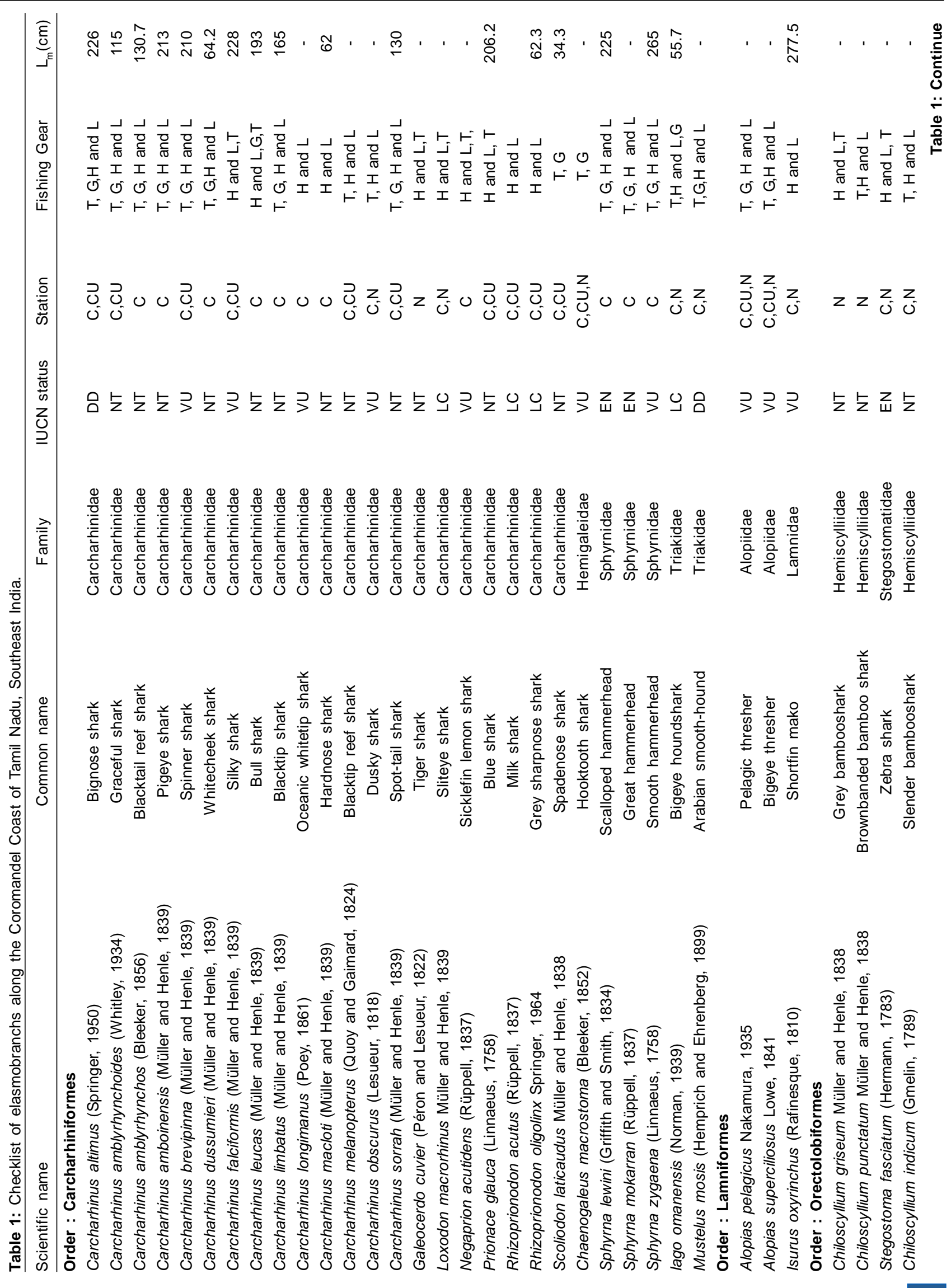

Volume Issue 


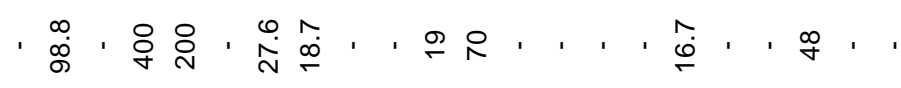

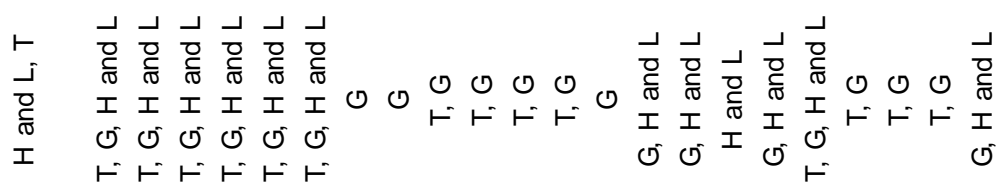

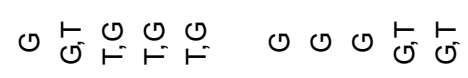

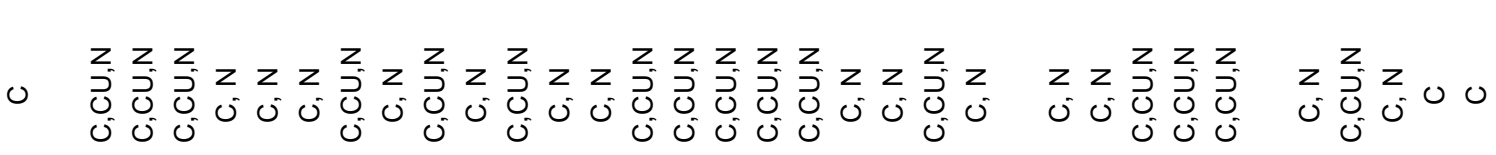

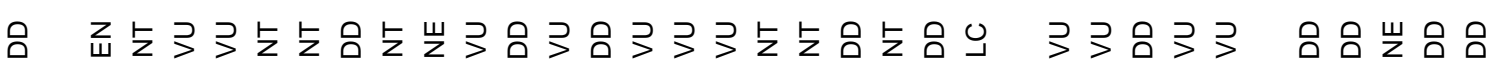
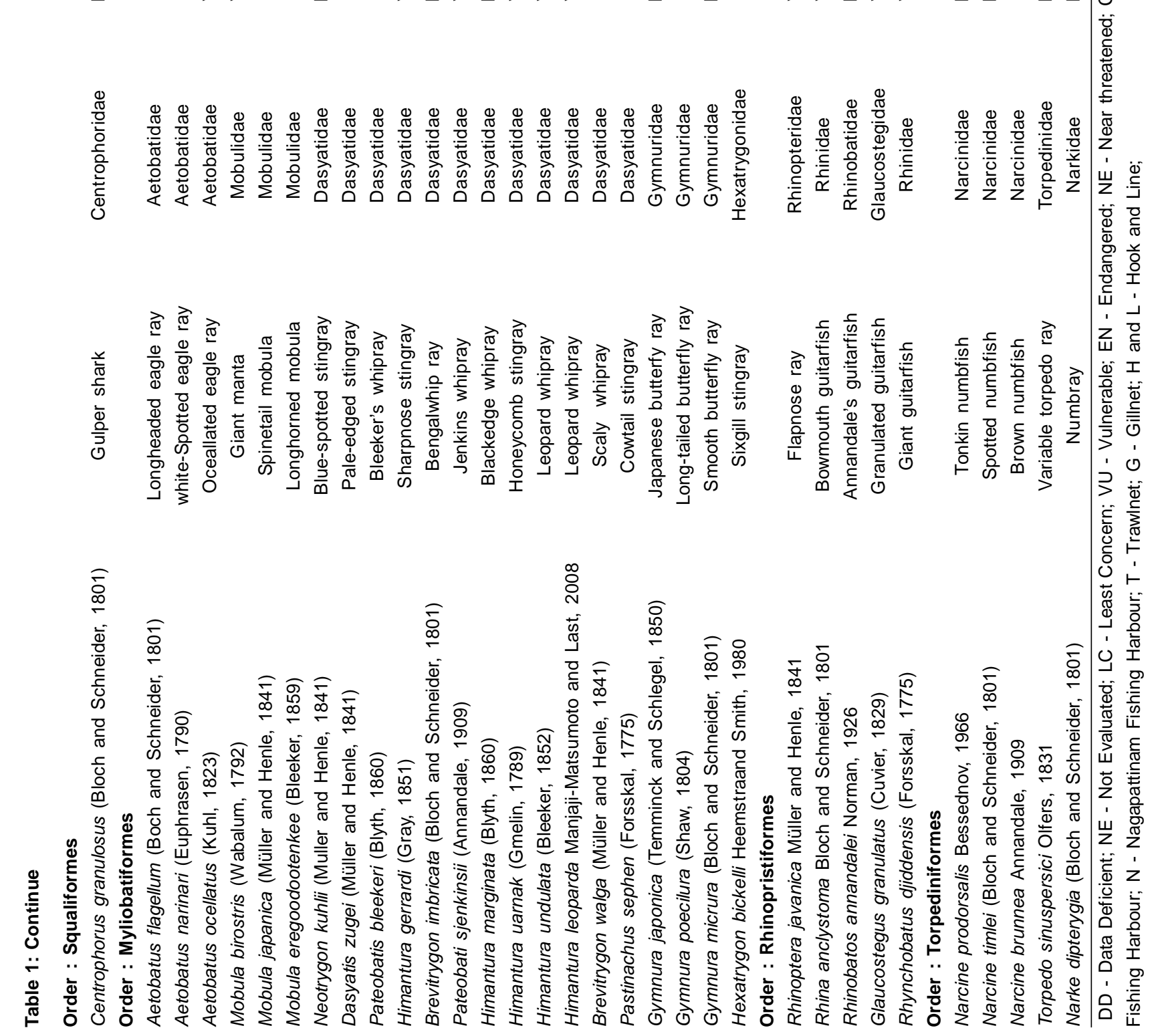

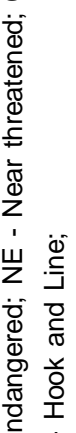


4 species (7\%) under 'Least Concern', 22 species (33\%) under 'Near Threatened', 22 species (33\%) under 'Data Deficient', 12 species (18\%) and four species (6\%) under 'Endangered' and 4 species (4\%) under 'Not Evaluated' by IUCN (Fig 4). In present study, among the elasmobranchs,

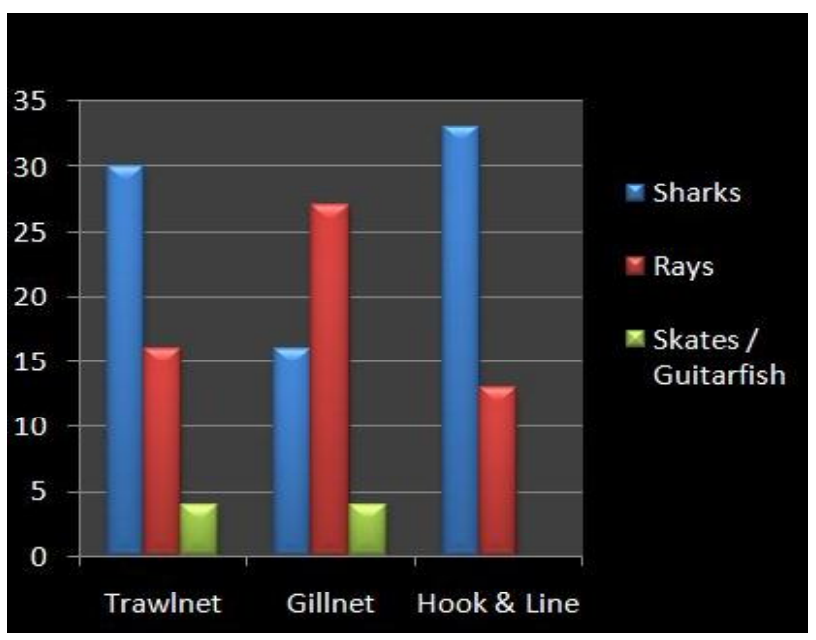

Fig 2: Gear-wise elasmobranch composition. sharks were noted to be caught by long line (42\%), followed by trawl net (33\%) and gillnet (22\%) and rays were observed to be caught by gillnet (48\%), followed by trawlnet (29\%) and hook and line (23\%) and skates/guitarfishes were observed to be caught equally by trawl net and gillnet each with $50 \%$ along the Coromandel Coast of Tamil Nadu. Analysis of gear-wise catch composition of elasmobranch species revealed that Trawlnet contributed the highest with $35 \%$, followed by gillnet (33\%) and Hook and Line (32\%) along this coast (Fig 2). Earlier studies by Mohanraj et al. (2009) reported that trawlnet contributed (4\%), gillnet (16\%) and hook and line (2\%) along the Chennai Coast. Similar study by Manojkumar et al. (2012) reported that the contribution of elasmobranch in trawlnet (43\%), gillnet $(31.3 \%)$ and longline (21\%) at Malabar Coast. This is in agreement with the present study wherein, elasmobranch species was majorly caught by trawl net followed by gill net, hook and line and others.

It is very important to evolve a management plan for elasmobranch fisheries as India is a major shark fishing nation and sharks are highly vulnerable to fishing. Developing strategies for conservation and management

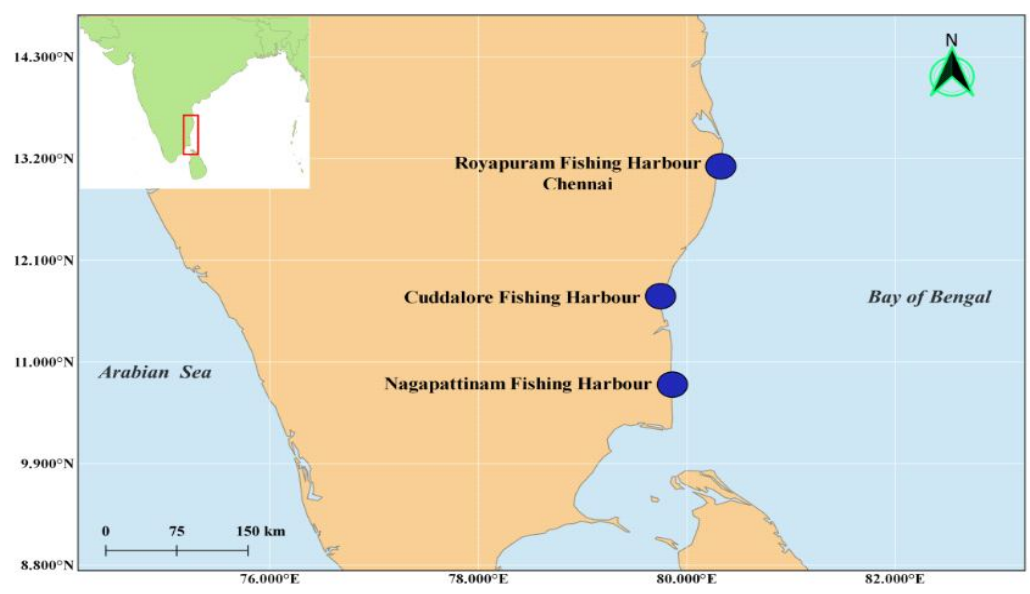

Fig 3: Map showing the study area of Coromandel Coast of Tamil Nadu, Southeast India.

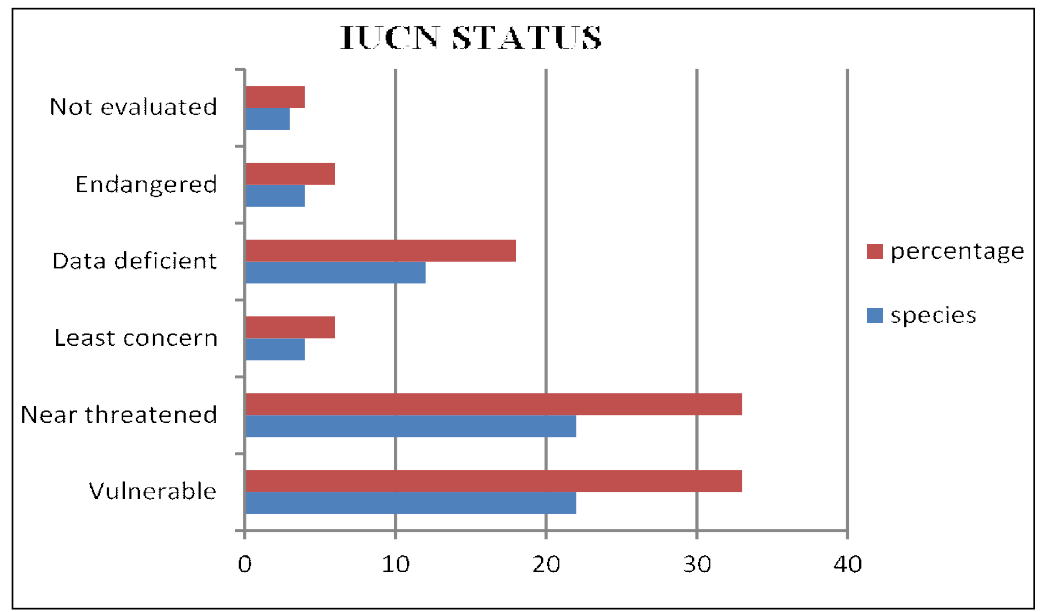

Fig 4: IUCN Status of Elasmobranchs. 
of elasmobranch populations become increasingly important globally, especially because many species are exceptionally vulnerable to overflshing. As elasmobranchs are one of the most vulnerable groups due to their biological characteristics, appropriate strategies need to be implemented for the sustainable exploitation and conservation of these elasmobranch resources.

\section{CONCLUSION}

A proper understanding of elasmobranch biodiversity and life history patterns is necessary for evolving species-specific fishery management plans that can be successfully implemented within spatio-temporal boundaries. In India, Tamil Nadu is known for shark fishery. The output of the present study is expected to yield fruitful information that would help to manage elasmobranch fishery in a sustainable way. On the other hand, an intensive stock assessment studies should be undertaken for the highly exploited elasmobranch species. In addition, 'closed seasons' and the ban of trawlers in particular area should be enforced. The mesh size regulations need to be implemented strictly to avoid the exploitation of undersized elasmobranchs. In this context, the present checklist is expected to help to evolve strategies for the sustainable utilization and conservation of these decreasing resources along the Coromandel Coast of Tamil Nadu, Southeast India.

\section{REFERENCES}

Akhilesh, K.V., Bineesh, K.K., Gopalakrishnan, A., Jena, J.K., Basheer, V.S. and Pillai N.G K. (2014). Checklist of Chondrichthyans in Indian waters. Journal of Marine Biological Association, India. 56: 15-17.

CMFRI (2019). Annual Report 2018-19. Central Marine Fisheries Research Institute, Kochi. 320 p.

CMFRI (2020). Marine Fish Landings in India - 2019.

Compagno, L.J.V. (1984). FAO Species Catalogue. Vol. 4. Sharks of the world. An annotated and illustrated catalogue of shark species known to date. Part 2. Charcharhiniformes. 125: 251-655.

Compagno, L.J.V. (1984). FAO Species Catalogue. Sharks of the world. An annotated and illustrated catalogue of shark species known to date. Part 1, Hexanchiformes to Lamniformes. FAO. Fisheries Synopsis, 125: 24-129.

Fischer, W. and Bianchi, G., (1984). FAO species identification sheets for fishery purposes: Western Indian Ocean (Fishing Area 51). Chimaeras. Sharks. v. 6: Alphabetical index of scientific names and vernacular names.
Froese, R. and Pauly, D. (2015). FishBase 2015: World Wide Web electronic publication. Google Scholar.

Ganesh, K. and Geetha, D.B. (2017). Biodiversity status and conservation strategy of elasmobranchs (sharks) at Gulf of Mannar, Thoothukudi district. International Journal of Multidisciplinary Research and Development. 2349-4182.

Gowthaman, (2011). Biodiversity of elasmobranch resources of Gulf of Mannar. M.F.Sc. Thesis. TANUVAS, Chennai, India. 98.

Joshi, K.K., Sreeram, M.P., Zacharia, P.U., Abdussamad, E.M., Varghese, M., Habeeb Mohammed, O.M.M.J. and George, G. (2016). Check list of fishes of the Gulf of Mannar ecosystem, Tamil Nadu, India. Journal of the Marine Biological Association of India. 58: 34-54.

Karuppasamy, K., Jawahar, P., Kingston, S.D., Venkataramani, V.K. and Vidhya, V. (2020). Elasmobranch diversity, conservation and management along Wadge Bank, South India. Indian Journal of Animal Research. 54: 367-372.

Kizhakudan, S.J., Akhilesh, K.V., Thomas, S., Yousuf, K.S.S.M., Sobhana, K.S., Purushottama, G.B., Muktha, M., Dash, S.S., Manojkumar, P.P., Nair, R.J. and Najmudeen, T.M. (2018). Field identification of batoids-a guide to Indian species.

Manojkumar, P.P., Zacharia, P.U. and Pavithran, P.P., (2012). Fishery of elasmobranchs with some observations on the biology and stock assessment of Carcharhinus limbatus (P. Muller and Henle, 1839) exploited along Malabar coast. Indian Journal of Fisheries. 59(4): 35-41.

Misra, K.S. (1969). Elasmobranchii and holocephali. The fauna of India and the adjacent countries. Pisces (Second Edition). Zoological Survey of India, Government of India Press, Faridabad, pp.1-276.

Mohanraj, G., Rajapackiam, S., Mohan, S., Batcha, H. and Gomathy, S. (2009). Status of elasmobranchs fishery in Chennai, India. Asian Fisheries Science. 22(2): 607-615.

Raje, S.G., Sivakami, S., Mohanraj, G., Manojkumar, P.P., Raju, A. and Joshi, K.K. (2007). Atlas on the Elasmobranch fishery resources of India. CMFRI Special Publication 95: 1-253.

Theivasigamani, M. and Subbiah, S. (2014). Elasmobranch fishery resources of Gulf of Mannar, Southeast coast of India. World Journal of Fish and Marine Sciences. 6: 24-29.

Thilaka, V.S.V. (2018). Biodiversity and biology of sharks along south Tamil Nadu coast. M.F.Sc. Thesis. Fisheries College and Research Institute, Thoothukudi, Tamil Nadu Dr. J. Jayalalithaa Fisheries University.

Venkataraman, K., Milton, J. and Raghuram, K.P. (2003). Handbook on sharks of Indian waters. Zoological Survey of India. 